\title{
Global constitutionalism and cultural diversity: The emergence of jurisgenerative constitutionalism in Africa
}

\author{
B ER I H U N A D U G N A G B E Y E \\ University of Göttingen \\ Email: berihunadugna.gebeye@uni-goettingen.de
}

\begin{abstract}
This article examines the path of global constitutionalism and its encounter with cultural diversity in Africa. It situates the phenomenon of global constitutionalism in the late nineteenth century and traces some of its tectonic transformations since the inauguration of the liberal international order. Besides referring to the processes of and calls for the constitutionalization of the international legal regime and the emergence of global constitutional law, global constitutionalism played a constitutive role for constitutionalism in Africa. As constitutionalism in Africa is configured within a biosphere of global constitutionalism and cultural diversity, their dynamic interplay leads to the emergence of jurisgenerative constitutionalism, which is procedurally and normatively open to accommodate a plural conception of rights, justice and values. As a result, what is constitutionally permissible and what is not cannot simply be determined by an attachment to either global constitutionalism or cultural diversity. Rather, it is the interaction of global constitutionalism and cultural diversity in time and place that dictates what the constitutional practice or outcome should look like. By taking the women's rights jurisprudence related to customary and Islamic laws and the phenomenon of Shariacracy as themes of analysis, and Nigeria as a case study, this article explores how the emergence of jurisgenerative constitutionalism mediates global constitutionalism and cultural diversity in Africa. By bringing in the African experience, the article sheds some light on the range of theoretical and practical possibilities available to the emerging field of global constitutionalism.
\end{abstract}

Keywords: Africa; cultural diversity; global constitutionalism; international legal regime; jurisgenerative constitutionalism; Nigeria

\section{Introduction}

We are living in the age of constitutional varieties. ${ }^{1}$ Global constitutionalism is one variety of constitutionalism, albeit an emerging one, that tries to

${ }^{1}$ M Tushnet, 'Varieties of Constitutionalism' (2016) 14 International Journal of Constitutional Law 1, 1-5. 
capture and explain the processes of constitutionalization in global society. ${ }^{2}$ On the one hand, global constitutionalism is a project that considers the international legal sphere as a constitutionalist regime and advocates for the application of constitutionalist norms and frameworks. ${ }^{3}$ On the other hand, it refers to the phenomenon of the migration of constitutional ideas and practices among states and the subsequent convergence of constitutional designs and practices around the world. ${ }^{4}$ In both ways, it is claimed, the inauguration of the United Nations system is the starting point: faith in and commitment to the values of human rights, democracy and the rule of law form the 'constitutionalist trinity' of global constitutionalism. ${ }^{5}$ However, as this article shows, global constitutionalism did not start with the inauguration of the United Nations system, nor are human rights, democracy and the rule of law its only underlying values. Global constitutionalism predates the United Nations system and has had different values, such as imperial or colonial domination and subjugation, in the Global South. What seems to unite global constitutionalism, past and present, is what James Tully called 'the empires of uniformity' that projects some tenet of cultural uniformity in a world of cultural diversity. ${ }^{6}$

While the constitutionalization of international law and the global convergence of constitutional systems attract relatively significant scholarly attention, how global constitutionalism influences and is influenced by other constitutional and cultural systems is not studied adequately. ${ }^{7}$ By exploring and examining the interaction of global constitutionalism and cultural diversity in Africa, this article aims to present not only the convergences of constitutionalism at the global level, but also the divergences and the ways in which competing and divergent constitutional values or commitments coexist and operate within states.

Africa offers a unique opportunity to study global constitutionalism in its historical accounts, transformations and current trends. First, global

2 A Wiener, JL Dunoff, J Havercroft, M Kumm and K Kovács, 'Global Constitutionalism as Agora: Interdisciplinary Encounters, Cultural Recognition and Global Diversity’ (2019) 8 Global Constitutionalism 1, 5-6.

3 A Peters, 'The Merits of Global Constitutionalism' (2009) 16 Indiana Journal of Global Legal Studies 397, 397-398; M Kumm, 'The Legitimacy of International Law: A Constitutionalist Framework of Analysis' (2004) 15 European Journal of International Law 907, 907-31.

${ }^{4}$ R Hirschl, 'Opting Out of 'Global Constitutionalism" (2018) 12 The Law \& Ethics of Human Rights 1, 1-2; M Rosenfeld, 'Is Global Constitutionalism Meaningful or Desirable?' (2014) 25 European Journal of International Law 177, 178.

${ }^{5}$ M Kumm, AF Lang Jr, J Tully and A Wiener, 'How Large is the World of Global Constitutionalism?’ (2014) 3 Global Constitutionalism 1, 3-4.

${ }^{6} \mathrm{~J}$ Tully, Strange Multiplicity: Constitutionalism in an Age of Diversity (Cambridge University Press, Cambridge, 1995) 82-83.

${ }^{7}$ Hirschl (n 4). 
constitutionalism has been one of the constitutive elements of constitutionalism in Africa. This is because international law incorporated Africa into the world society as a colony in the late nineteenth century and recognized it as an equal sovereign within the community of nations in the mid-twentieth century in the form of the European-style territorial state. Along with international law, European laws had been imported to regulate the internal operations of the new territorial states during colonialism, and liberal constitutional norms and principles had been imposed to Africa as a condition for independence. As a result, international law, imported laws and liberal constitutional norms and practices set the geographical and theoretical contours of constitutionalism in Africa.

Second, with the end of the Cold War and the triumph of liberal democracy, global constitutionalism influenced the constitutional designs of many African states as liberal constitutional ideas migrated and spread globally. ${ }^{8}$ The post-1990s constitutions in Africa heavily draw their normative values and institutional frameworks from international human rights law and the experience of liberal constitutional democracies from both sides of the Atlantic. ${ }^{9}$ They adopted forms, structures and discursive practices from liberal constitutionalism. Because of this, the empires of uniformity inherent in global constitutionalism are heavily present in the design and practice of constitutionalism in Africa.

However, global constitutionalism played a constitutive role and spread to Africa not onto a tabula rasa, but rather configured in a biosphere of cultural diversity. Such configuration has involved different levels of acceptance, rejection, resistance, and mutual recognition between global constitutionalism and cultural diversity. Accordingly, the quest to establish a constitutional government based on human rights, democracy and the rule of law includes a simultaneous demand for the accommodation of cultural diversity.

Third, the dual commitment to global constitutionalism and cultural diversity set the operation of jurisgenerative constitutionalism in Africa in motion. Consequently, that which is constitutionally permissible and that which is not cannot simply be determined by allegiance to global constitutionalism or an affinity with cultural diversity. It is the jurisgenerative interactions of global constitutionalism and cultural diversity in time and place that dictate what the constitutional practice or outcome should look like. The singularity of the constitutional order, therefore, lies not in having a

${ }^{8}$ R Hirschl, Towards Juristocracy: The Origins and Consequences of the New Constitutionalism (Harvard University Press, Cambridge MA, 2007).

9 See CM Fombad, 'Internationalization of Constitutional Law and Constitutionalism in Africa' (2012) 60 The American Journal of Comparative Law 439, 444-56. 
singular conception of justice, rights and values, but in its ability to mediate global constitutionalism and cultural diversity. As such, the constitutional experiment in Africa is jurisgenerative, unlike the jurispathic constitutionalism, where a hierarchy of laws, normative orders and assumptions trump divergent and plural conception of rights, justice and values.

Building on Robert Cover's Nomos and Narrative, ${ }^{10}$ this article aims to explore and examine how jurisgenerative constitutionalism mediates global constitutionalism and cultural diversity in Africa. It begins by exploring the ways in which global constitutionalism played a constitutive role for constitutionalism in Africa and proceeds to discuss the continuous negation and affirmation of global constitutionalism on the continent. It then examines how a dual commitment to global constitutionalism and cultural diversity arose, and how the latter is advanced in part through the former. The final part presents how jurisgenerative constitutionalism mediates global constitutionalism and cultural diversity by taking women's rights under customary and Islamic laws and the phenomenon of Shariacracy as themes of analysis, and Nigeria as a case study. Nigeria is an excellent case study for examining the emergence of jurisgenerative constitutionalism in both its redemptive role and as a means of securing insular autonomy within the constitutional universe.

\section{Global constitutionalism in Africa}

Much of the scholarship on global constitutionalism considers the postWorld War II period as the starting point, with human rights, democracy and the rule of law as the underlying values, and the Global North as a site for the experimentation of global constitutionalism. In this regard, the United Nations system and its animating values form the core of global constitutionalism. ${ }^{11}$ The study of the constitutional systems - mostly constitutional rights of the United States, United Kingdom, Germany, Canada and France - constitute the globalization of constitutional law. ${ }^{12}$ Indeed, these are manifestations of global constitutionalism. Nonetheless, global constitutionalism did not start with the inauguration of the United Nations system, nor are human rights, democracy and the rule of law its only underlying values or a handful of Western states its representative sample.

${ }^{10}$ RM Cover, 'The Supreme Court, 1982 Term - Foreword: Nomos and Narrative' (1983) 97 Harvard Law Review 4.

11 ED Wet, 'The International Constitutional Order' (2006) 55 International \& Comparative Law Quarterly 51.

12 VA da Silva, 'How Global is Global Constitutionalism? Comments on Kai Moller's The Global Model of Constitutional Rights' (2014) 10 Jerusalem Review of Legal Studies 175. 
Global constitutionalism predated the United Nations system and had different values than it has today in the Global South. For instance, global constitutionalism and its application in Africa have two epochs. The first is the application of global constitutionalism and its underlying values from the Berlin West Africa Conference to independence - that is, global constitutionalism during colonialism. This period can be considered as global constitutionalism 1.0. The second is the application and transformation of global constitutionalism in Africa since independence - global constitutionalism in the postcolonial period - which can be considered as global constitutionalism 2.0. In order to appreciate the constitutive role of global constitutionalism for constitutionalism in Africa and to understand the ways in which global constitutionalism interacts with cultural diversity, it is important to look briefly at global constitutionalism in time and space.

Global constitutionalism 1.0 had its genesis in the late nineteenth century, during the scramble for Africa, and its underlying values were free trade and the extension of the alleged European civilization to African societies. As multiple European states showed colonial interest in Africa, a non-state legal regime that regulates their relationships and arbitrates the disputes that might arise in the scramble was necessary. This situation positioned international law as constitutional law in late colonialism. ${ }^{13}$ However, international law neither recognized the personality of precolonial African states and societies nor provided a theory of international relations that included them. ${ }^{14}$ As a result, Africa was a place without rights and duties under international law. ${ }^{15}$ Consequently, it was considered as a terra nullius and thus a legitimate object of occupation and conquest by European states. This was evident in the Berlin West Africa Conference of 1884-85, which acted as a 'Constitutional Law' or 'Basic Law' for colonial Africa.

Based on the General Act of the Berlin Conference and its frames of reference, Africa was constituted into new territories, peoples, governments and sovereignties. Accordingly, precolonial states and societies were forced

13 M Craven, 'Between Law and History: The Berlin Conference of 1884-1885 and the Logic of Free Trade' (2015) 3 London Review of International Law 31, 49-54; A Anghie, Imperialism, Sovereignty and the Making of International Law (Cambridge University Press, Cambridge, 2007) 90-91.

${ }^{14}$ IJ Gassama, 'International Law, Colonialism, and the African' in MS Shanguhyia and T Falola (eds), The Palgrave Handbook of African Colonial and Postcolonial History (Palgrave Macmillan, New York, 2018) 554-59; M wa Mutua, 'Why Redraw the Map of Africa? A Moral and Legal Inquiry' (1995) 16 Michigan Journal of International Law 1113, 1120-22.

15 See also JT Gathii, 'Africa' in B Fassbender and A Peters (eds), The Oxford Handbook of the History of International Law (Oxford University Press, Oxford, 2012) 408-26. Indeed, there was a paradox in this as colonial powers can enter into treaties with African tribes. This is an act of recognition and, according to Taslim Elias Olawale, Africans participated in this part of international law. 
to come together and/or separated from each other to form new territorial colonial states as their rights and sovereignties were unrecognizable by nineteenth-century international law. Instead, international law helped for the institution of colonial government and colonial sovereignty over and alien to African societies. By doing so, international law incorporated what Achille Mbembe called the 'founding violence' into the constitution of Africa. ${ }^{16}$ On the one hand, it created the right of colonization and the space within which it was exercised; on the other, it excluded the indigenous constitutions and made the colonial constitutions supreme. ${ }^{17}$

Building on and furthering the tenets of the General Act of the Berlin Conference, colonial powers imported their own laws to their colonies in Africa. These colonial laws brought legitimation and maintenance violence to colonial states. ${ }^{18}$ The legitimation violence was brought to Africa with the importation of imperial and colonial laws to justify, order and structure colonial government. To ensure the maintenance, spread and permanence of the colonial government, colonial powers further enacted new laws and rules required by the exigencies of the situation in every colony. In this way, colonial powers reimagined and organized their African colonies in different ways. International law and colonial laws therefore worked in tandem to constitute and operate colonial Africa. Obviously, this was not motivated by the values of human rights, democracy and the rule of law, nor was it demanded by African societies. Its chief aim was the exploitation and subordination of Africans. The constitutional role of international law and the importation of European laws to Africa during colonialism formed the core of global constitutionalism 1.0.

However, as Lauren Benton observes, the formation of colonial legal cultures involved legal contests, jurisdictional politics and governmentality considerations between European colonial powers and indigenous societies. ${ }^{19}$ In Africa, the encounter of global constitutionalism 1.0 with indigenous constitutional orders brought at least four outcomes. First, the encounter led to the rejection of the indigenous constitutional orders as constitutional orders. They were no longer supreme normative orders within their own respective political communities. Second, however, the encounter also led to the recognition of the indigenous legal orders in the form of customary law. And the application of customary laws was subject to a repugnancy clause and conformity with any other colonial laws. Third, the

16 A Mbembe, On the Postcolony (University of California Press, Berkeley, CA, 2001) 25.

17 General Act of the Berlin Conference on West Africa 1885, articles 34 \& 35.

18 Ibid; M Mamdani, Define and Rule: Native as Political Identity (Harvard University Press, Cambridge MA, 2012) 43-44.

19 See L Benton, Law and Colonial Cultures: Legal Regimes in world History, 1400-1900 (Cambridge University Press, Cambridge, 2004) 153-160. 
encounter led to further expansion and/or restriction of the domain of customary law. Fourth, and finally, the encounter even contributed to the invention of new customary laws. Ultimately, this encounter transformed both the nature and identity of global constitutionalism 1.0 and the indigenous constitutional orders. On the one hand, it created unity at the constitutional level by affirming the supremacy of global constitutionalism 1.0, but on the other, it recognized diversity at the sub-constitutional level by incorporating customary law as part of the colonial legal order.

As the right to self-determination of all peoples and the sovereign equality of all nations gained momentum after World War II, global constitutionalism 1.0 underwent a huge transformation in Africa. On the one hand, international law recognized the right to self-determination of all people, including those under colonial or alien subjugation. The United Nations Resolution 1514, in particular, considered, 'The subjection of peoples to alien subjugation, domination and exploitation constitutes [as] a denial of fundamental human rights' and consequently opened a strong international consensus for decolonization. ${ }^{20}$ On the other hand, the departing colonial powers imposed the system of constitutional democracy for the newly independent African states. As a result, the underlying values of global constitutionalism 1.0 transformed to the promotion of human rights, democracy and the rule of law based on the principle of equality of all peoples and states. This set in motion the operation of global constitutionalism 2.0. In a huge departure from the theoretical and ideological underpinnings of its predecessor, global constitutionalism 2.0 enabled the newly independent African states to join the community of nations and outlined their internal operation in a manner consistent with human rights, democracy and the rule of law. However, as will be discussed in the remainder of this article, like global constitutionalism 1.0, the underlying values of global constitutionalism 2.0 has been a subject of negation and affirmation due to cultural diversity.

From the African perspective, there is a paradox related to global constitutionalism 2.0. It arises from the demand and urgent need for global constitutionalism 2.0 and the simultaneous quest for its deconstruction and reconstruction. The decolonization struggle builds on the international law principle of self-determination and the sovereign equality of states that should and must be extended to Africans. The canonical expression of this is the recognition of these principles in the Charter of the Organization of African Unity (now African Union) in 1963. Such recognition maintained the colonial borders intact and provided the geographical contours for the

${ }^{20}$ A Getachew, Worldmaking After Empire: The Rise and Fall of Self-Determination (Princeton University Press, Princeton, NJ, 2019) 72-74. 
postcolonial experiment of self-determination. At the same time, the decolonization struggle and the Pan African movement also aimed at reordering the world free from hierarchies and domination. ${ }^{21}$ This required the deconstruction of the legal, political and economic institutions of the global realm that made colonization and domination possible. ${ }^{22}$ Yet again, global constitutionalism 2.0 played a constitutive role for the newly independent African states as international law defined the territories, peoples and sovereignties of these states and as independence constitutions determined the type of government for these states along with liberal constitutionalism. Hence African states are operating within the shadow of global constitutionalism, which has imperial and colonial roots in the continent.

\section{The continuous negation and affirmation of global constitutionalism 2.0 in Africa}

Global constitutionalism 2.0 has been a subject of continuous negation and affirmation in postcolonial Africa. To start from the positive side, there has been an affirmation of the territorial borders, peoples and sovereignties of the colonial states that postcolonial states inherited. As noted above, the territories of colonial states were legalized by the OAU/AU. People living in these territories further developed territorial nationalism. As Crawford Young notes, the catastrophic failure of postcolonial states to provide basic security, freedoms and opportunities erases neither the attachment of citizens to their states nor the hope that their states can be reformed. ${ }^{23}$ In spite of the prevalent ethno-linguistic and religious diversities, tensions and conflicts, secessionist movements are rare. ${ }^{24}$ In the more than the 50 states that make up the continent of Africa, secessionist movements have been raised in limited numbers by specific groups in specific states. For instance, the Katanga in Congo, the Biafra in Nigeria, the Cabinda in Angola, the Casamance in Senegal, the South Sudan in the Sudan and Eritrea in Ethiopia are notable instances of secessionist movements; of these, only the South Sudanese and Eritrean secession movements resulted in the creation of new states. $^{25}$ Moreover, behind these secessionist movements are a real or

21 Ibid 2-3.

22 M Mutua and A Anghie, 'What is TWAIL?' (2000) 94 Proceedings of the Annual Meeting (American Society of International Law) 31, 31.

${ }^{23}$ C Young, The Postcolonial State in Africa: Fifty Years of Independence, 1960-2010 (University of Wisconsin Press, Madison, WI, 2012) 314.

${ }^{24}$ Ibid.

25 SA Dersso, Taking Ethno-Cultural Diversity Seriously in Constitutional Design: A Theory of Minority Rights for Addressing Africa's Multi-Ethnic Challenge (Martinus Nijhoff, The Hague, 2012) 51-52. 
imagined lack of cultural recognition and political participation and representation in the national states. ${ }^{26}$ Hence the concept of the 'people' as constituted in global constitutionalism 2.0 has been accepted. So has the idea of sovereignty of the people and the state. Since independence, African states have expressly declared and affirmed the supremacy of their constitutions over any other normative order. ${ }^{27}$ To these extents, there has been an affirmation of the constitutive elements of global constitutionalism 2.0.

There has also been an initial affirmation of the theory of government engineered by independence constitutions. In sharp contrast to the colonial theory of unlimited government, independence constitutions incorporated and/or imposed a limited government for the newly independent states. Largely mirrored after the constitutional systems of the former colonizers, independence constitutions established either a Westminster style parliamentary system or a French style presidential system with horizontal, and in some cases vertical, separation of powers with checks and balances and recognized fundamental human rights. ${ }^{28}$ Further, they made electoral democracy the only basis for accessing government power and provided the rules of election as well. Therefore, Africa was set to begin its selfgovernment under a system of constitutional democracy and the newly independent states accepted this.

Aside from the legitimacy deficit of the independence constitutions ${ }^{29}$ in general, and the continuity of the Queen of England as a titular head of state for the former British colonies in particular, the theory of government engineered by these constitutions were defensible in retrospect. ${ }^{30}$ This is due to the fact that the quest to have a limited government under a system of multi-party democracy and the protection of human rights has permeated the constitutional and political struggles of postcolonial Africa to date. ${ }^{31}$ As

26 Ibid 60.

27 This is famously characterized as the phenomenon of constitutionalism without constitutionalism. See HWO Okoth-Ogendo, 'Constitutions without Constitutionalism: Reflections on an African Political Paradox' in D Greenberg, SN Katz, MB Oliviero and SC Wheatley (eds), Constitutionalism and Democracy: Transitions in the Contemporary World (Oxford University Press, Oxford, 1993) 65-84.

28 VT Le Vine, 'The Fall and Rise of Constitutionalism in West Africa' (1997) 35 The Journal of Modern African Studies 181, 184-87; YP Ghai, 'Constitutions and the Political Order in East Africa' (1972) 21 The International and Comparative Law Quarterly 403, 410-13; RB Seidman, 'Constitutions in Independent, Anglophonic, Sub-Saharan Africa: Form an Legitimacy Law and Society’ (1969) 1969 Wisconsin Law Review 83, 99-110.

29 BO Nwabueze, Constitutionalism in the Emergent States (C Hurst, London, 1973) 24-28.

30 See R Mattes and M Bratton, Do Africans Still Want Democracy? Afrobarometer Policy Paper No 36 (Afrobarometer, Accra, 2016) 1-27.

31 See EN Sahle, 'Introduction' in EN Sahle (ed), Democracy, Constitutionalism, and Politics in Africa: Historical Contexts, Developments, and Dilemmas (Palgrave Macmillan, New York, 2017) 1-4; PA Nyong'o, Popular Struggles for Democracy in Africa (Zed Books, London, 1987). 
a result, the idea of limited government in independence constitutions had moral legitimacy if not sociological legitimacy at the time. ${ }^{32}$ Nonetheless, the desire to manufacture the legitimacy of the new states and governments, and the urge and need to change from a monarchy to a republic in the case of former British colonies, were understandable. ${ }^{33}$ By their condition, the newly independent states were compelled to overcome the inherent contradictions of their being born from a colony and yet being expected to reimagine independence and operate in a decisive break from the colonial past. ${ }^{34}$ In these attempts, independence constitutions were changed or altered and the idea of limited government and multi-party democracy were rejected as alien and colonial impositions. ${ }^{35}$

Among the four fundamental elements of the state - territory, people, sovereignty and government - the theory of government has been the primary subject of affirmation and negation in the experiment of constitutionalism in Africa. Soon after independence, one-party systems replaced multiparty democracy, and personal rule displaced separation of powers and checks and balances by claiming to fulfil the fruits of independence nation-building, development and overall social transformation - and to ground and institute a government based on African autochthonous conceptions and new realities. ${ }^{36}$ The new African leaders argued that the limited government instituted by the independence constitutions was a hurdle for development, social transformation and nation building in addition to its origin and nature being alien to the African experience. It was contended that an African theory of government should accelerate development, enable government and bestow on the state the power and resources it needs to defeat 'African real enemies - ignorance, poverty and diseases'. ${ }^{37}$ In this light, it was claimed that multiparty democracy was a brake and a recipe for tribalism.

Accordingly, one-party systems were constitutionalized, and the powers of presidents were enlarged in the republican constitutions. Such constitutional undertakings were rationalized on the basis of the alleged existence of an African system of government favouring consensus and cooperation over

32 A constitution can be morally justifiable if it has an inherent trustworthiness in its substantive standards of justice, although it may be imposed. For details, see RH Fallon, 'Legitimacy and the Constitution' (2005) 118 Harvard Law Review 1787, 1794-96.

${ }_{33}$ Nwabueze (n 29) 23.

34 L Gandhi, Postcolonial Theory: A Critical Introduction (Allen \& Unwin, Sydney, 1998) 6.

35 Nwabueze (n 29) 28-30.

36 Young (n 23) 16-19; P Ahluwalia, Politics and Post-Colonial Theory: African Inflections (Routledge, London, 2002) 56-59.

${ }^{37}$ HK Prempeh, 'Africa's 'Constitutionalism Revival': False Start or New Dawn?' (2007) 5 International Journal of Constitutional Law 469, 475. 
competition, the unity of power rather than its division and the centrality of a unifying personality such as a king or chief in precolonial times. ${ }^{38} \mathrm{How}-$ ever, these claims were false - not only because there were in fact numerous governance systems in precolonial Africa, but also because these systems had inbuilt systems of separation of powers and checks and balances. Nevertheless, the new leaders centralized and personalized both the powers of the government and their political parties, and made themselves the main sources of power and wealth in the newly independent states. ${ }^{39}$

However, the practice of one-party systems and personal rules did not bring economic development and a unified nation, nor did it confer the much-needed legitimacy to the state and government. ${ }^{40}$ The primacy of personal patronage, loyalty to and dependence on the presidency over constitutional rules and laws for opportunities in politics and in business drained the newly independent states' hope for development and progress. ${ }^{41}$ The tendency and propensity towards corruption among those in government (public sector) and their affiliates in business (private sector), and the similar drive to exit among those marginal to these systems, further weakened the legitimacy of the states and governments. ${ }^{42}$ The newly independent states became captives to their new presidents and their cronies, and vulnerable to capture by their opponents when circumstances permitted. Claims of nation-building and development turned out to be justifications for the personal rule of presidents and, at the same time, organizing principles for state capture by their opponents. ${ }^{43}$ Further, the ethnic, religious and regional diversities in these newly independent states made one-party systems and personal rules unpalatable and unappealing to many, especially minorities. ${ }^{44}$

${ }^{38}$ HK Prempeh, 'Presidential Power in Comparative Perspective: The Puzzling Persistence of Imperial Presidency in Post-Authoritarian Africa' (2007) 35 Hastings Constitutional Law Quarterly $761,764-65$.

39 See RH Jackson and CG Rosberg, Personal Rule in Black Africa: Prince, Autocrat, Prophet, Tyrant (University of California Press, Berkeley, CA, 1982).

40 See also PA Nyong'o, 'Africa: The Failure of One-Party Rule' (1992) 3 Journal of Democracy 90, 90-96.

${ }^{41} \mathrm{M}$ Bratton and N van de Walle, 'Neopatrimonial Rule Regimes and Political Transitions in Africa' (1994) 46 World Politics 453, 458.

${ }^{42}$ M Mamdani, Citizen and Subject: Contemporary Africa and the Legacy of Late Colonialism (Princeton University Press, Princeton, NJ, 1996) 11.

${ }^{43}$ B Davidson, The Black Man's Burden: Africa and the Curse of the Nation-State (Three Rivers Press, New York, 1992) 290-94; L Laakso and AO Olukoshi, 'The Crises of the PostColonial Nation-State Project in Africa' in AO Olukoshi and L Laakso (eds), Challenges to the Nation-State in Africa (Nordic Africa Institute, Uppsala, 1996) 11-16; C Ake, 'The Unique Case of African Democracy' (1993) 69 International Affairs 239, 239.

${ }^{44}$ See also P Roessler, Ethnic Politics and State Power in Africa: The Logic of the Coup-Civil War Trap (Cambridge University Press, Cambridge, 2016) 60-81. 
As these states were held hostage by their political elites, the military (either invited by the prevailing circumstances or responding to their own interests) moved into the realm of politics by transforming its role from protecting the territorial integrity of the state to cleansing it of 'incorrigible politicians' ${ }^{45}$ With the exception of a few states where one-party autocracies survived from the late 1960s up to the end of the 1980s, the military took over power from the civilian regimes in many African states. ${ }^{46}$ While the military justified its intervention on claims of the failure of constitutional governments, the prevalence of corruption and bad governance on the part of the civilian leaders, it subscribed to the theory of government and used the playbooks of the civilian leaders it deposed. ${ }^{47}$

The military leaders aimed to civilize or demilitarize their powers by either adopting a new constitution or altering only a few parts of the one-party state constitutions. They had neither the commitment to practise constitutionalism, nor the interest to transfer power to a civilian regime, ${ }^{48}$ nor the will to deliver good governance and prevent corruption while in office. ${ }^{49} \mathrm{It}$ is no wonder that there were 80 successful coups, 108 failed attempts, and 139 reported plots in 48 African states between 1956 and $2001 .{ }^{50}$ The ultimate objective of the military leaders was to institutionalize their personal powers under a theory of unlimited government, like their civilian predecessors. ${ }^{51}$

Nonetheless, the general distaste, protest, and struggle against unlimited government at home, and the triumph of liberal democracy abroad with the end of the Cold War, ${ }^{52}$ coerced African states to reaffirm and accept liberal constitutionalism with multi-party democracy in the 1990s. Starting in

45 See P Nugent, Africa Since Independence: A Comparative History (2 $2^{\text {nd }}$ ed, Palgrave Macmillan, New York, 2012) Ch 6; GK Kieh Jr, 'Military Engagement in Politics in Africa' in GK Kieh Jr and PO Agbese (eds), The Military and Politics in Africa: From Engagement to Democratic and Constitutional Control (Ashgate, Farnham, 2004) 37-54; S Decalo, 'Military Coups and Military Regimes in Africa' (1973) 11 The Journal of Modern African Studies $105,105-27$.

${ }^{46}$ Young (n 23) 16-19.

47 See also S Decalo, Coups and Army Rule in Africa: Studies in Military Style (Yale University Press, New Heaven, CT, 1976).

${ }^{48}$ Even if the military handed over power to the civilian regimes after the military coup in Ghana and Nigeria, they later recaptured power from the civilian regimes: see Nugent (n 45) Ch 6.

49 Okoth-Ogendo (n 27) 78.

50 PJ McGowan, 'African Military Coups d'état, 1956-2001: Frequency, Trends and Distribution' (2003) 41 The Journal of Modern African Studies 339, 339; See also GSM Okeke, 'Theories of Military in African Politics' in SO Oloruntoba and T Falola (eds), The Palgrave Handbook of African Politics, Governance and Development (Palgrave Macmillan, New York, 2018) 219-36.

51 Okoth-Ogendo (n 27) 78.

52 See F Fukuyama, The End of History and the Last Man (The Free Press, New York, 1992). 
Algeria with the opening up of multi-party elections in 1988, and followed by the organization of a national conference for democratic transition in Benin in 1990, the 'tsunami of democratization swept over Africa' throughout the $1990 \mathrm{~s} .{ }^{53}$ For better or worse, multiparty democracy with the protection of some fundamental human rights under a constitutionally limited government, has been put forward to address the troubles of postindependence, such as political instability, dictatorship, bad governance, grave violations of human rights, corruption and pervasive poverty. With few exceptions, ${ }^{54}$ the majority of African states revised or adopted brand new constitutions that incorporated and affirmed the principles of democratic politics, established independent constitutional review systems along with independent constitutional institutions and recognized fundamental human rights and freedoms.

Even though the post-Cold War African constitutions have had a better vitality and influence in terms of shaping and taming the actions and behaviours of African governments than the previous constitutions, they have carried over the authoritarian textures of their predecessors, negating their liberal constitutional promises and commitments. In addition to affirming the idea of limited government in a constitutional democracy as a matter of constitutional law and politics, these constitutions indeed helped the peaceful transfer of power through elections to end the tenure of presidents for life, to enable courts to annul unconstitutional legislative and executive actions and decisions, ${ }^{55}$ to contribute to the emergence of the nascent free media and civil society and to create space for human rights practices. ${ }^{56}$ Despite these positive developments, multiple decades of these constitutional experiments have led to the development of dominant and singleparty systems, ${ }^{57}$ maintained authoritarian rules and practices, ${ }^{58}$ and faced

${ }^{53}$ Young (n 23) 26-27; see also SP Huntington, The Third Wave: Democratization in the Late Twentieth Century (University of Oklahoma Press, Norman, OK, 1993).

${ }^{54}$ For instance, Botswana only revised its 1966 Constitution in 2005.

55 Recently, the Supreme Court of Kenya annulled the presidential election result for election irregularities, ordering a re-election. See Raila Amolo Odinga and other v independent Electoral and Boundaries Commission and others, Presidential Petition No 1 of 2017, Supreme Court of Kenya (2017). See also R Ellett, Pathways to Judicial Power in Transitional States: Perspectives from African Courts (Routledge, London, 2013) 6-7.

56 Prempeh, 'Africa's “Constitutionalism Revival”' (n 37) 471-72.

57 G Erdmann and M Basedau, 'An Overview of African Party Systems' in R Doorenspleet and L Nijzink (eds), One-Party Dominance in African Democracies (Lynne Rienner, Boulder, CO, 2010) 25-46; M Bogaards, 'Counting Parties and Identifying Dominant Party Systems in Africa' (2004) 43 European Journal of Political Research 173, 173-97.

58 See G Lynch and G Crawford, 'Democratization in Africa 1990-2010: An Assessment' (2011) 18 Democratization 275, 275-310. 
the resurgence of personal rules ${ }^{59}$ and sometimes military coups. ${ }^{60}$ Thus, as Michel Rosenfeld notes, the postcolonial constitutional experiment in Africa is a dialectic process that involves a continuous affirmation and absorption of global constitutionalism 2.0 as implanted on the eve of independence, and a negation and rejection of the same as these states operate in a system of constitutional government. ${ }^{61}$

\section{The simultaneous demand for global constitutionalism 2.0 and recognition of cultural diversity}

Out of the continuous negation and affirmation of global constitutionalism 2.0, two developments emerge in the practice of constitutionalism in Africa today. The first is (at least in principle) a normative commitment to and an unequivocal acceptance of democracy, human rights and the rule of law in constitutional government. Although there are challenges in practically translating these commitments, no African state can comfortably claim today that democracy, human rights and the rule of law are alien values or secondary to development and nation-building. Contemporary constitutional politics in Africa rests on how to safeguard and advance these values and what sort of constitutional designs are necessary to this end. The second development is how to accommodate ethnic and religious diversity in the normative and institutional frameworks of constitutions. The simultaneous demand for global constitutionalism 2.0 and recognition of cultural diversity are some of the major agendas of constitutional politics in twenty-first century Africa.

59 See Cranenburgh (n 5) 952-73; L Diamond, 'The Rule of Law versus the Big Man’ (2008) 19 Journal of Democracy 138, 138-49.

${ }^{60}$ For instance Niger (2010), Mali (2012), Guinea Bissau (2012), Lesotho (2014) and Burkina Faso (2017) had military coups: see V Baudais and G Chauzal, 'The 2010 Coup d'état in Niger: A Praetorian Regulation of Politics?' (2011) 110 African Affairs 295, 295-304; Adam Nossiter, 'Soldiers Overthrow Mali Government' The New York Times, 22 March 2012, <https:// wwwnytimescom/2012/03/23/world/africa/mali-coup-france-calls-for-electionshtml>; A Nossiter, 'Guinea-Bissau Coup Removes Presidential Front-Runner' The New York Times, 13 April 2012, $<$ https://wwwnytimescom/2012/04/14/world/africa/guinea-bissau-coup-removes-presidential-frontrunnerhtml>; E Benyera, 'Towards an Explanation of the Recurrence of Military Coups in Lesotho' (2017) 3 ASPJ Africa \& Francophonie 56, 56-73; H Taoko, 'African Leaders Call for Reinstatement of President of Burkina Faso' The New York Times, 21 December 2017, <https:/wwwnytimescom/ 2015/09/23/world/africa/military-coup-burkina-fasohtml>.

${ }^{61}$ M Rosenfeld, 'Constitutional Identity' in M Rosenfeld and A Sajó (eds), The Oxford Handbook of Comparative Constitutional Law (Oxford University Press, Oxford, 2012) 766; M Rosenfeld, The Identity of the Constitutional Subject: Selfhood, Citizenship, Culture, and Community (Routledge, London, 2010) 179-80. 
Inherent in the demand for global constitutionalism 2.0 is the outstanding quest to institute a limited government. For this, many African states devised vertical and horizontal divisions of power, incorporated fundamental individual and group rights, and underlined the independence of the judiciary. Decentralization ${ }^{62}$ and term and/or age limits of executives ${ }^{63}$ are some of the buzzwords in recent African constitutional design and scholarship. During constitution-making and implementation, many African states build on some common constitutional lessons learned within and outside Africa. ${ }^{64}$ Moreover, some African states even innovate new constitutional institutions and mechanisms in defence of constitutionalism, human rights, and the rule of law. ${ }^{65}$ The overarching objective of these constitutional solutions is to tame the unconstrained executive power that has bedevilled many African states since independence. Even though the normative commitments to limited government vary among African states, there is a pressing need to have it is agreed upon across the continent.

Furthermore, the issue of constitutionalism figures prominently in the African Union legal framework, so constitutional democracy is not a matter entirely left to states. In response to the recurring coups d'état and the neverending processes of constitutional change, the African Union adopted a Charter on Democracy, Elections and Governance (the Charter) in 2007 to collectively protect constitutionalism and democratic governance. The objectives of this Charter as outlined in article 2 include adherence to the universal values of democracy, human rights, the rule of law and constitutionalism. Article 10, in particular, obliges states parties to entrench the principle of constitutional supremacy, to amend or revise their constitutions only based on national consensus including a referendum and to protect the right to equality as a fundamental precondition for a just and democratic society.

These are not simply mere aspirations without a practical impact on the constitutional behaviour of state parties. The African Court on Human and Peoples' Rights takes practical steps to enforce these constitutional

${ }^{62}$ CM Fombad, 'Constitutional Entrenchment of Decentralization in Africa: An Overview of Trends and Tendencies' (2018) 62 Journal of African Law 175.

${ }^{63}$ DM Tull and C Simons, 'The Institutionalisation of Power Revisited: Presidential Term Limits in Africa' (2017) 52 Africa Spectrum 79; M Wiebusch and C Murray, 'Presidential Term Limits and the African Union' (2019) 63 Journal of African Law 131.

${ }^{64}$ See CM Fombad, 'Designing Institutions and Mechanisms for the Implementation and Enforcement of the Constitution: Changing Perspectives in Africa' (2017) 25 African Journal of International and Comparative Law 66, 66-90.

${ }^{65}$ See CM Fombad, 'The Diffusion of South African-Style Institutions? A Study in Comparative Constitutionalism' in R Dixon and T Roux (eds), Constitutional Triumphs, Constitutional Disappointments: A Critical Assessment of the 1996 South African Constitution's Local and International Influence (Cambridge University Press, Cambridge, 2018) 359-87. 
standards. ${ }^{66}$ For instance, in Actions Pour la Protection des Droits de L'Homme (APDH) v. The Republic of Cote d'Ivoire, the African Court on Human and Peoples' Rights found the composition of the Electoral Commission to be in violation of the Charter and incompatible with the right to equality before the law and equal protection by the law as recognized under article 10(3). ${ }^{67}$ Moreover, there are also sub-regional mechanisms that contribute to the collective protection of constitutionalism and democratic governance in various regions of Africa. ${ }^{68}$ Hence these supranational and national constitutional mechanisms are directed towards taming the Leviathan, and show (at least in principle) the acceptance of global constitutionalism 2.0 in Africa. ${ }^{69}$

The recognition of cultural diversity and the Africanization of constitutionalism work in tandem with the commitment to global constitutionalism 2.0. Cultural diversity is brought into constitutions in part through the rationalities and discourses of global constitutionalism 2.0, and in part due to the need to contextualize constitutionalism with the socioeconomic, cultural and political realities of each state. Traditional authorities or chieftaincy as an institutional framework and customary and Islamic laws as normative orders are the major aspects of cultural diversity that figure in many constitutions. For instance, there are five major ways in which traditional authorities are incorporated into the institutional frameworks of constitutions in Africa. The first is direct incorporation into the legislature, the second is through the institution of separate houses, the third is inclusion as part of local government, the fourth is by being part of the judiciary and the fifth and final one is incorporation through an innovative institutional recreation. ${ }^{70}$

In a similar vein, while the specific subject matters and procedures of application differ between states, customary and Islamic laws are generally applicable in personal and family matters. ${ }^{71}$ Furthermore, even if

${ }^{66}$ See AK Abebe, 'Taming Regressive Constitutional Amendments: The African Court as a Continental (Super) Constitutional Court' (2019) 17 International Journal of Constitutional Law 89, 89-117.

${ }^{67}$ Actions Pour la Protection des Droits de L'Homme (APDH) v. The Republic of Cote d'Ivoire, App. No. 001/2014, Judgment of Nov. 18, 2016; Ben Kioko, 'The African Charter on Democracy, Elections and Governance as a Justiciable Instrument' (2019) 63 Journal of African Law 39, 49-55.

${ }^{68}$ See BR Dinokopila, 'The Impact of Regional and Sub-Regional Courts and Tribunals on Constitutional Adjudication in Africa', in CM Fombad (ed), Constitutional Adjudication in Africa (Oxford University Press, Oxford, 2017).

69 See also N Steytler, 'Domesticating the Leviathan: Constitutionalism and Federalism in Africa' (2016) 24 African Journal of International and Comparative Law 272.

70 See BA Gebeye, 'Legal Syncretism: A Theoretical Framework for Understanding African Constitutionalism' (unpublished SJD thesis, Central European University, 2019) Ch 3.

${ }^{71}$ F Banda, Women, Law and Human Rights: An African Perspective (Hart, Oxford, 2005) $34-36$. 
predominantly unnoticeable in African constitutional practice and scholarship, the concept of duties permeates the entire Bill of Rights. Despite variations in the extent of duties and the place where they are stipulated, more than 40 African constitutions incorporate the notion of individual duties along with rights. ${ }^{72}$ Surely, as part of a legally binding written constitution, the concept of duties raises unique constitutional questions if implemented.

The recognition of traditional authorities, and customary and Islamic laws, and the concept of duties in domestic constitutions partly spring from the African Charter on Human and Peoples' Rights that Africanizes the theory and practice of human rights on the continent. This was powerfully stated by Leopold Senghor, then the president of Senegal, as follows:

Room should be made for [the] African tradition in our Charter on Human and Peoples' Rights, while bathing in our philosophy, which consists in not alienating the subordination of the individual to the community, in co-existence, in giving everyone a certain number of rights and duties. In Europe, Human Rights are considered as a body of principles and rules placed in the hands of the individual, as a weapon, thus enabling him to defend himself against the group or entity representing it. In Africa, the individual and his rights are wrapped in the protection of the family and other communities ensure everyone ... If we want to build the Homo africanus of tomorrow, we should once again, assimilate without being assimilated. We should borrow from modernism only that which does not misrepresent our civilization and deep nature. ${ }^{73}$

Thus, inasmuch as there is a commitment to global constitutionalism 2.0 and its underlying values, there is a simultaneous demand for the recognition of cultural diversity in the design and practice of constitutionalism in Africa. The dual commitment to global constitutionalism 2.0 and cultural diversity in the same constitutional space presents unique experiments in constitutionalism, to which I now turn.

\section{$\mathrm{V}$. The emergence of jurisgenerative constitutionalism}

The simultaneous commitment to global constitutionalism 2.0 and cultural diversity has led to the operation of jurisgenerative constitutionalism. That which is constitutionally permissible and that which is not cannot simply be

\footnotetext{
72 See also C Heyns and W Kaguongo, 'Constitutional Human Rights Law in Africa' (2006) 22 South African Journal on Human Rights 673, 712.

${ }^{73}$ F Ouguergouz, The African Charter of Human and People's Rights: A Comprehensive Agenda for Human Dignity And Sustainable Democracy in Africa (Martinus Nijhoff, The Hague, 2003) $377-78$.
} 
determined by an attachment to either global constitutionalism 2.0 or cultural diversity. It is the interaction of these systems in time and place that dictates what the constitutional practice or outcome should look like. The singularity of the constitutional order lies not in having a singular conception of justice, rights and values, but rather in its ability to provide a framework within which various pluralities exist and operate within the polity. As such, the constitutional order is procedurally and normatively open to accommodate seemingly competing pluralisms.

In this regard, Cover's idea of jurisgenesis in Nomos and Narrative provides aid in understanding African constitutionalism. It will therefore be useful to briefly restate Cover's central idea in Nomos and Narrative. Cover posits that law and narrative are inseparable that that, 'No set of legal institutions or prescriptions exists apart from the narratives that locate it and give it meaning. ${ }^{74} \mathrm{He}$ continues, 'Once understood in the context of the narratives that give it meaning, law becomes not merely a system of rules to be observed, but a world [nomos] in which we live. ${ }^{75}$ The nomos, the normative world, we inhabit is held together by a narrative, the force of interpretive commitments. ${ }^{76}$ Nomos and narrative exist and operate in a cultural medium that involves individuals, communities and the state, and that is not free from the shadow of power and violence. Precisely because of the power dynamics and the accompanying violence, narratives can be either nomos maintaining or nomos building. The narratives of the state, such as those of its officials and courts, are nomos maintaining in the sense that they suppress or subordinate all other alternative nomos and narratives. ${ }^{77}$ However, the narratives of the paideic communities, such as religious, ethnic or other non-state communities, are nomos building as they try to ensure their insular autonomy/self-government or to redeem the entire normative universe. ${ }^{78}$ Unlike the jurispathic narratives of nomos maintaining that strive to ensure a supreme and singular nomos, narratives of nomos building are jurisgenerative and accordingly create multiple spaces, contestations and possibilities that build and transform the nomos.

As constitutional jurisgenesis happens in a normative universe where the state is an important actor, Cover suggests that the state can - and should participate in and contribute to nomos building. The state can do so by being aware of the legitimate existence of multiple nomos and narratives of the paideic communities, and by being tolerant (even if it is painful) of their

74 Cover (n 10) 4.

75 Ibid 4-5.

76 Ibid 7.

77 Ibid 40-44.

78 Ibid 25-35. 
practical application. ${ }^{79}$ At the same time, the paideic communities should accept some powers of the state, even if it is jurispathic. ${ }^{80}$ Cover explains the interdependence between the state and the paideic communities by arguing that

no normative world has ever been created or maintained wholly in either the paideic or the imperial [state] mode ... Any nomos must be paideic to the extent that it contains within it the commonalities of meaning that make continued normative activity possible. Law must be meaningful in the sense that it permits those who live together to express themselves with it and with respect to it. It must both ground predictable behavior and provide meaning for behavior that departs from the ordinary. ${ }^{81}$

In this regard, Cover notes how the courts kill and destroy the law using their power of violence, and how they also ensure peace by asserting 'a regulative function that permits a life of law rather than violence'. ${ }^{82}$

Building on Cover's Nomos and Narrative, I now turn to explain how jurisgenerative constitutionalism mediates global constitutionalism and cultural diversity in Africa. Along with the paideic communities such as ethnic and religious groups, the African state participates in and contributes to the enterprise of nomos building. I take the right to equality as one example of liberal rights and the constitution as a supreme legal code in the universe of global constitutionalism on the one hand, and women's rights in customary and religious laws and Shariacracy as an aspect of cultural diversity on the other. By closely examining these aspects of global constitutionalism and cultural diversity, I aim to show how jurisgenerative constitutionalism plays a redemptive role with regard to women's rights and customary laws by transforming the world of the customary towards equality and justice. At the same time, I will also show how jurisgenerative constitutionalism creates possibilities for the operation of religious law and Shariacracy within the normative universe of the constitutional order. Nigeria is an excellent case study through which to examine jurisgenerative constitutionalism in both its redemptive role and as a means of securing insular autonomy within the constitutional universe.

The constitutional jurisgenesis in Nigeria starts with the normative commitment to a liberal conception of equality and to equality as understood by its ethnic and religious communities. This is due to the fact that the

79 Ibid 15-17; J Resnik, 'Living Their Legal Commitments: Paideic Communities, Courts, and Robert Cover Symposium: Rethinking Robert Cover's Nomos and Narrative: Essay' (2005) 17 Yale Journal of Law \& the Humanities 17, 25.

${ }^{80}$ See also Resnik (n 79) 25.

${ }^{81}$ Cover (n 10) 14.

${ }^{82}$ Ibid 53. 
Constitution reaffirms the liberal account of rights by extending it to everyone without any discrimination based on sex. At the same time, it imports the notion of rights as found in customary and religious practices by recognizing customary and Islamic laws. By transcending the universalism versus cultural relativism dichotomy in the human rights debate, the Constitution considers customary and Islamic laws to be both manifestations of the right to culture and freedom of religion, and avenues for the enforcement of human rights, including women's rights. Moreover, some Muslim Northern states developed a constitutional meaning or a narrative that allows them to live their socioeconomic and political lives according to the dictates of Sharia, referred to here as Shariacracy. Although some of the underlying values and laws of Sharia are fundamentally contradictory to the normative universe of the Constitution, the Nigerian state and its institutions tolerate and even support Shariacracy.

In doing so, as Cover suggests, the Nigerian state recognizes the legitimate existence of multiple nomos and narratives within its constitutional order. As discussed below, the paideic communities also recognize the power of the state to take some actions to maintain the constitutional order. The recognition of multiple nomos and narratives by the state and the acceptance of the 'imperial mode' of the state by the paideic communities contribute to the maintenance and building of the constitutional normative universe.

While jurisgenerative constitutionalism explains the empirical phenomenon of the existence of multiple nomos and narratives within the African constitutional order, one has to draw a clear distinction from the outset between the potential of jurisgenerative constitutionalism for mediating the liberal account of rights with the African notion of rights and its potential for mediating system-threatening constitutional systems such as Shariacracy and constitutional democracy. With regard to rights, jurisgenerative constitutionalism has the potential to create better options for the practice of human rights than the universalists and cultural relativists can offer, as it brings the state and the society together in the practice of human rights, and consequently gives society the agency and structure to engage with the broader constitutional universe in light of its cultural understanding. By translating and localizing the abstract and universal ideas of human rights in culturally accessible and legally and politically meaningful ways, such human rights practice transforms both cultural practices and universal human rights, not only from above (especially through apex court decisions), but also from below (through a change in the cultural understanding of the society). In this respect, jurisgenerative constitutionalism has good potential in human rights practice. In mediating system-threatening constitutional systems such as Shariacracy and constitutional democracy, however, it should be a constitutional design and practice of last resort. To begin 
with, the Nigerian experience with Shariacracy is the exception rather than the norm in Africa, and one should resort to constitutional jurisgenesis in the most unlikely scenario that some system-threatening constitutional systems arise as an empirical matter and the territorial integrity of a state is at stake. Nonetheless, the momentary experience of constitutional jurisgenesis and the way in which it manifests is worth exploring in and of itself, as I attempt to show in the context of women's rights and Shariacracy.

\section{Women's rights}

Women's rights represent one of the main intersections in the debate between universalism and cultural relativism in human rights. Universalists claim that culture poses a serious challenge to the enjoyment of women's rights, as such cultures are produced by and operate in patriarchal systems. Hence, to protect and ensure the rights and interest of women, human rights should have primacy over cultural systems. ${ }^{83}$ Cultural relativists contend that human rights are part of the cultural experience of every society, and consequently culture should inform the substantive content and enforcement of human rights. ${ }^{84}$ As a result, the theory and practice of human rights should not be judged simply by the cultural understanding of Western societies that brought the so-called 'universal human rights' ${ }^{85}$ Both the universalist and cultural relativist account of human rights are jurispathic as they claim that their values, morals and convictions are supreme.

However, the universal account of human rights is not without problems for women, and the cultural relativist view is not without advantages. Feminist scholars reveal how the human rights discourse and structure place women in a disadvantaged position. ${ }^{86}$ In a similar vein, some scholars also demonstrate how cultural systems protect the rights and interests of women ${ }^{87}$ and how women are changing their cultures from within to more egalitarian value systems. ${ }^{88}$ Thus, despite the universalism and cultural

${ }^{83}$ SM Okin, 'Is Multiculturalism Bad for Women?' in J Cohen, M Howard and MC Nussbaum (eds), Is Multiculturalism Bad for Women? Susan Moller Okin with Respondents (Princeton University Press, Princeton, NJ, 1999) 22-24.

${ }^{84}$ M Mutua, Human Rights: A Political and Cultural Critique (University of Pennsylvania Press, Philadelphia, PA, 2009) 74-81.

${ }^{85}$ AA An-Na'im, 'Toward a Cross-Cultural Approach to Defining International Standards of Human Rights: The Meaning of Cruel, Inhuman, or Degrading Treatment or Punishment' in AA An-Na'im (ed), Human Rights in Cross-Cultural Perspectives: A Quest for Consensus (University of Pennsylvania Press, Philadelphia, PA, 1999) 25-29.

${ }^{86}$ See G Binion, 'Human Rights: A Feminist Perspective' (1995) 17 Human Rights Quarterly 509, 509-26.

87 See A Helium, 'Human Rights and Gender Relations in Postcolonial Africa: Options and Limits for the Subjects of Legal Pluralism' (2000) 25 Law \& Social Inquiry 635.

${ }^{88}$ M Sunder, 'Piercing the Veil' (2002) 112 Yale Law Journal 1399, 1402-04. 
relativism debate, culture influences the structure, perception, adjudication and enforcement of human rights and, in turn, human rights influence and shape the development of culture. ${ }^{89}$ Furthermore, as Sally Engle Merry observes, the cultural translation of human rights localizes the so-called universal human rights, concomitantly transforming both culture and universal human rights. ${ }^{90}$

In what seems to be a recognition of the limitations of both the universalists' and cultural relativists' claims and its own dual commitments, as noted above, the Nigerian Constitution recognizes both the rights rooted in the liberal tradition and those found in cultural and religious systems. By doing so, the Constitution sets a jurisgenerative approach to the construction of nomos and narratives with respect to rights. Building on this jurisgenerative approach, the courts of Nigeria recognize the dual commitment to both global constitutionalism 2.0 and cultural diversity, and when possible take a redemptive approach to justice and equality with regard to customary laws, maintaining the insular autonomy of Muslims and their Islamic laws.

In Mojekwu v. Mojekwu, ${ }^{91}$ for example, the rights of women's inheritance under customary law was at issue. Under the oli-Ekpe custom of South Eastern Nigeria (Igbo), women do not have a right to inheritance as it is the exclusive right of men. Based on this customary law, the appellate, $\mathrm{Mr}$ Augustine Mojekwu, instituted a claim against Mrs Caroline Mojekwu to inherit her deceased husband's property. The appellate argued that as the deceased had no son or brother, the deceased's property should go to him as the deceased was his paternal uncle and he was the closest male relative. The Court of Appeal, based on the facts and evidence produced, decided that another customary law called Kola Tenancy was applicable in this case. Under this law, women are entitled to inherit the deceased's property as men. The court further observed that the oli-Ekpe custom that excluded women from inheritance was not only contrary to public policy and repugnant to natural justice, equity and good conscience, but was also against the Constitution and international human rights standards that Nigeria had ratified.

However, the jurispathic pronouncement of the Court of Appeal was watered down by the Supreme Court in its appellate judgment of Mojekwu v. Iwuchukwu. ${ }^{92}$ While the Supreme Court upheld the decision and holding

89 F Lenzerini, The Culturalization of Human Rights Law (Oxford University Press, Oxford, 2014) 213-17.

90 See SE Merry, Human Rights and Gender Violence: Translating International Law to Local Justice (University of Chicago Press, Chicago, 2006).

91 Mojekwu v Mojekwu 7 NWLR 283 (1997).

92 Mojekwuv Iwuchukwu 4 SC (2004) (Pt II). Mrs Iwuchukwu, the daughter of Mrs Caroline Mojekwu, substituted as a party to the case as her mother died. 
of the Court of Appeal, it reversed the opinion on the oli-Ekpe custom of inheritance. Justice S.O. Uwaifo on behalf of the Supreme Court stated that:

I cannot see any justification for the court below to pronounce that the Nnewi native custom of '[o]li-ekpe' was repugnant to natural justice, equity and good conscience ... the learned justice of appeal was no doubt concerned about the perceived discrimination directed against women by the said Nnewi 'oli-ekpe' custom and that is quite understandable. But the language used made the pronouncement so general and far[-]reaching that it seems to cavil at, and is capable of causing strong feelings against, all customs which fail to recognise a role for women. For instance, the custom and traditions of some communities which do not permit women to be natural rulers or family heads. The import is that those communities stand to be condemned without a hearing for such fundamental custom and tradition they practice by the system by which they run their native communities. ${ }^{93}$

As seen from this comment of the Supreme Court, the fact that customary law discriminates against women does not ipso facto lead to the conclusion that such laws are unconstitutional. Further, it also suggests that the exact substance and contours of women's rights in relation to customary laws will be determined and delimited on a case by case basis after consideration of all competing interests.

Following this approach, the Supreme Court reaffirmed women's rights of inheritance by declaring Igbo customary law to be discriminatory and unconstitutional in Ukeje $v$ Ukeje. ${ }^{94}$ In its decision, the Court notes:

No matter the circumstances of the birth of a female child, such a child is entitled to an inheritance from her late father's estate. Consequently, the Igbo customary law which disentitles a female child from partaking, in the sharing of her deceased father's estate is in breach of section 42(1) and (2) of the Constitution, a fundamental rights provision guaranteed to every Nigerian. The said discriminatory customary law is void as it conflicts with section $42(1)$ and (2) of the Constitution. ${ }^{95}$

In a similar case of Anekwe $v$ Nweke, ${ }^{96}$ the Supreme Court declared a customary law that prevents a widow and her female child from inheriting her husband's property to be repugnant to national justice, equity and conscience, and accordingly void. Unlike the previous case, which relies on the Constitutional provisions of equality, the court applied a public

93 Mojekwu v Iwuchukwu 4 SC (2004) (Pt II).

94 Mrs Lois Chituru Ukeje \& Anorv Mrs Gladys Ada Ukeje 27 WRN 127 (2001).

95 Mrs Lois Chituru Ukeje \& Anorv Mrs Gladys Ada Ukeje 27 WRN 127 (2001), paras 32-33.

96 Anekwe v Nweke 234 LRCN 34 (2014). 
policy test in outlawing a customary law of widow and women disinheritance. ${ }^{97}$ Although both cases ensure the equal rights of women and men in inheriting property, the accounts of women's rights in customary laws have to be judicially litigated to ascertain their substance and delimit their contours in the constitutional framework. ${ }^{98}$

In the language of Cover's Nomos and Narrative, these cases are of a redemptive nature. First, the Supreme Court is aware of the legitimate alternative nomos and narratives with regard to women's rights under customary laws. Because of this, it engages with the ethnic communities as a corporate group endowed with their own nomos and narratives, and women as justice-seeking actors within their own customary systems and the broader constitutional order. The result of such constitutional jurisgenesis is the transformation of the normative universe of the customary towards gender equality and justice.

However, unlike customary laws, the courts' engagement with Islamic law is aimed at ensuring the insular autonomy and self-government of the Muslim community within the broader constitutional order. As a result, courts tolerate the alternative nomos and narratives that may be against some aspects of the constitutional order. For instance, in Karimatu Yakubu and Alhaji Mahmoud Ndatsu v. Alhaji Yakubu Tafida Paiko and Alhaji Umaru Gwagwada, the issue was who was entitled to give consent for the conclusion of a marriage. ${ }^{99}$ Under liberal constitutional standards, it is obvious that marriage is concluded by the free and full consent of the spouses. However, under Islamic marriage (the system under which the parties in this case concluded the marriage), the father (as a guardian of his daughter) can marry her off against her will. This itself is a violation of the constitutional right to equality and should therefore mark this law as unconstitutional. Indeed, the Area Court that first received the case found no difficulty in making the marriage invalid as it was concluded between Karimatu's father and her husband without her consent. ${ }^{100}$ However, the Sharia Court of Appeal in Sokoto reversed the decision of the Area Court by arguing that Karimatu's father had a right to compel his daughter to marriage under Islamic law. ${ }^{101}$ Although the Federal Court of Appeal in Kaduna reversed the decision of the Sharia Court of Appeal, it did so on

97 Ibid paras 64-65.

98 See also AA Oba, 'Religious and Customary Laws in Nigeria' (2011) 25 Emory International Law Review 881, 894.

99 Y Sodiq, A History of the Application of Islamic Law in Nigeria (Springer, Cham, 2017) 79.

100 Ibid 80.

101 Ibid 81. 
different grounds ${ }^{102}$ and reaffirmed the father's right to compulsion (ijbar) in marriage. ${ }^{103}$

In Hasana Gbaguda v. Muhammadu Gbaguda, Hasana filed an application to divorce her husband, Muhammadu, in the Area Court, alleging he beat her when he got drunk. ${ }^{104}$ Although Muhammadu admitted the allegations, the court denied Hasana's claim for divorce and further noted that if she wanted a divorce she had to pay compensation $(k h u l) .{ }^{105}$ Unhappy with the decision of the Area Court, she appealed to the Sharia Court of Appeal for divorce. The Sharia Court of Appeal decided in her favour by reasoning that her husband beat and abused her and, accordingly, he did not deserve any compensation. ${ }^{106}$ The fact that men can divorce through talaq (without compensation) and women should divorce through khul (with compensation) was neither considered as discriminatory against women nor even contested in this case. Furthermore, in Habiba Sarkin Fulani v. and Alhaji Dahiru Dayi, the appellant's right to divorce through khul was denied as she could not find evidence showing that she was mistreated by her husband. ${ }^{107}$ Obviously, in liberal constitutional systems, the outcomes of these cases would have been entirely different. These cases were decided with the application of Islamic law and predominantly by Sharia courts. The constitutional recognition of Islamic law in some personal and family matters and the establishment of Sharia courts means that constitutional practices that deviate from the liberal tenet of the Constitution are within the normative universe of the constitutional order.

\section{Shariacracy}

Beyond rights, jurisgenerative constitutionalism mediates system-threatening and competing constitutional systems such as constitutional theocracy and constitutional democracy within a constitutional order. Constitutional theocracy is a constitutional system that adopts a state religion and that takes religion as the main source (or one of the main sources) of legislation and adjudication, while constitutional democracy is a secular constitutional system that takes the democratic will of the people as the foundation of the constitutional order. ${ }^{108}$ While constitutional theocracy is the dominant

102 Once the father has given his daughter a choice to marry in the first place, he cannot revoke his promise.

103 Sodiq (n 99) 81-82.

104 Ibid 88.

105 Ibid.

106 Ibid 89.

107 Ibid 90-91.

108 R Hirschl, Constitutional Theocracy (Harvard University Press, Cambridge MA, 2010) 2-16. 
constitutional system of the non-secular world, constitutional democracy is a constitutional system of the secular world. But can constitutional theocracy and constitutional democracy coexist in a single polity? The answer is yes if the constitutional system of that polity operates in the system of constitutional jurisgenesis as it does in Nigeria.

The Nigerian constitutional order contains both theocratic, in the form of Shariacracy, and democratic constitutional systems. Shariacracy is the adoption of Sharia as the foundation of governance in a constitutional democracy. ${ }^{109}$ Despite the differences in the normative and institutional setups of Sharia and constitutional democracy, the former is advanced through the mechanisms of the latter and has been considered to be one of the manifestations of the 'dividends of democracy' and federalism. ${ }^{110}$

Shariacracy is not a twenty-first century constitutional and political big bang in Nigeria. The rise of Shariacracy is embedded in the socio-political and religious experience of Northern Nigeria and the national and international order in which it is situated. With the establishment of the Sokoto Caliphate by Jihadist Sheikh Usman Dan Fodio in 1804, Sharia had been fully operational in the Northern region until the British limited its application to civil matters subject to a repugnancy clause. ${ }^{111}$ Despite demands for Sharia in the public domain after independence, the political and military elites of Northern Nigeria, who have dominated national politics, did not give it an official expression. ${ }^{112}$ This has changed with a turn to civilian rule in 1999 under the leadership of Olusegun Obasanjo, the first non-Muslim, a popularly elected Southern Christian president of Nigeria. ${ }^{113}$ One reason for the rise of Shariacracy is the shift of power from the North to the South and the concomitant feeling of marginalization of the North by Obasanjo's presidency. In this respect, bringing Sharia into the public domain in the North is considered to be a 'political bargaining chip' in the federation. ${ }^{114}$ The other reason relates to the revival of cultural self-determination that has

109 AA Mazrui, 'Shariacracy and Federal Models in the Era of Globalization: Nigeria in Comparative Perspective' in ER McMahon and T Sinclair, Democratic Institution Performance: Research and Policy Perspectives (Praeger, Westport, CT, 2002) 66.

110 B Kendhammer, 'The Sharia Controversy in Northern Nigeria and the Politics of Islamic Law in New and Uncertain Democracies' (2013) 45 Comparative Politics 291, 297.

111 MHA Bolaji, 'Between Democracy and Federalism: Shari'ah in Northern Nigeria and the Paradox of Institutional Impetuses' (2013) 59 Africa Today 92, 98; for details, see AS Johnston, The Fulani Empire of Sokoto (Oxford University Press, Oxford, 1967).

112 RT Suberu, 'Religion and Institutions: Federalism and the Management of Conflicts Over Sharia in Nigeria' (2009) 21 Journal of International Development 547, 548-52; See also AU Iwobi, 'Tiptoeing through a Constitutional Minefield: The Great Sharia Controversy in Nigeria' (2004) 48 Journal of African Law 111.

113 Mazrui (n 109) 63.

114 Ibid. 
accompanied waves of centralization since independence. ${ }^{115}$ The inauguration of the Fourth Republic has brought about Yoruba nationalism and Igbo confederal demands, which have pushed the North to advance Shariacracy as a cultural and religious identity. The forces of globalization at the international level, with the South as its vanguard at the national level on the one hand, and the North's inability to compete within globalization on the other, have forced the North to resort to Sharia as a mode of resistance, both at home and abroad. The official reasons for Shariacracy, however, are related to practising religious rights and addressing corruption of the morals of the government and the governed through Sharia, consequently delivering development, social justice and good government. ${ }^{116}$

Although Nigeria has the largest Muslim population in Africa (including any other Arab country), ${ }^{117}$ Sharia has been reintroduced in a framework of a liberal democratic constitutional system. ${ }^{118}$ Ahmed Sani Yerima ran for the governorship of Zamfara state under a promise to implement Sharia through the state's legislature. ${ }^{119}$ Two months after his inauguration, he set up a law review committee and, based on its recommendation, proposed a Bill to fully implement Sharia penal law in the state through the adoption of Sharia penal and procedure codes, and the reorganization of the judiciary in line with the tenets of Sharia. The House of Assembly of the state adopted the law. ${ }^{120}$ Following Zamfara, eleven other Northern states - Kano, Katsina, Niger, Bauchi, Kaduna, Sokoto, Borno, Gombe, Kebbi, Jigawa and Yobe adopted Sharia into their criminal law domain. ${ }^{121}$ In addition to the extension of Sharia into the criminal justice system, Sharia has been central in the public policy priorities of the North with respect to the enforcement of rights, delivery of social justice and economic development, and in holding government officials accountable. ${ }^{122}$ Equal to the right to practise religion according to the dictates of Islam and the appeal of Sharia for the welfare of Muslims and their just development, its power in disciplining the conduct of leaders and containing corruption is no less fundamental in its reintroduction. ${ }^{123}$ In order

115 Ibid.

116 Kendhammer (n 110) 297-98; Bolaji (n 111) 111; see also M Krings, 'Conversion on Screen: A Glimpse at Popular Islamic Imaginations in Northern Nigeria’ (2008) 54 Africa Today 45.

117 Mazrui (n 109) 63.

118 Suberu (n 112) 552.

119 Kendhammer (n 110) 294; G Mills and others, Making Africa Work: A Handbook for Economic Success (Tafelberg, London, 2017) 234. Obasanjo notes that the governor's wish in introducing Sharia was to consolidate his power and secure his legitimacy.

${ }^{120}$ M Lawan, 'Islamic Law and Legal Hybridity in Nigeria' (2014) 58 Journal of African Law 303, 310 .

121 Bolaji (n 111) 93-94.

122 Kendhammer (n 110) 298.

123 Ibid. 
to shape the culture and principles of governance in light of the tenets of Islam, Islamic inspired institutions such as the Shari'ah, Zakkah and Hubusi Commissions, and the Hisbah Board, are established in these states. ${ }^{124}$

Not only is Shariacracy advanced in a liberal constitutional system, it also maintains the supremacy of the Constitution. The twelve Shariaimplementing states justify the reintroduction of Sharia into their states based on different sections of the Constitution, not by rejecting its existence or supremacy. ${ }^{125}$ For instance, they defend Shariacracy with reference to section 2(2), which proclaims that Nigeria shall be a federation; section 4 (7) (the legislative powers of the House of Assembly of states); section 6 (2\&4) (the power of the House of Assembly of States to establish courts); section 38 (freedom of religion); and section 277 (the jurisdiction of the Sharia Court of Appeal). Although the constitutionality of Shariacracy is a contentious matter in Nigerian political and public life, its advancement is claimed to have a constitutional basis. ${ }^{126}$ Furthermore, all these states affirm the supremacy of the Constitution with the Sharia reforms. ${ }^{127}$ While it is problematic to say that the full implementation of Sharia is compatible with the Constitution, Shariacracy is not advanced on the premise that Sharia is a supreme law and not subject to the standards of positive law.

Moreover, the Sharia proponents are not radical Muslims such as Boko Haram (who reject the constitutional system and want to create an Islamic state of Nigeria), ${ }^{128}$ but politicians who rely on the democratic votes of the people for their access to and time in government office. ${ }^{129}$ Furthermore, governors such as Ahmed Sani Yerima of Zamfara and his counterparts of the eleven Sharia-implementing states proposed Shariacracy within the prism of the federal structure. They did not demand Shariacracy for the whole of Nigeria, or even for all of Northern Nigeria. Further, even if Zamfara inspired some Northern states to adopt Shariacracy, not all the northern states have implemented Sharia reforms, nor have those that have implemented reforms always followed the Zamfara model. ${ }^{130}$ Out of the

124 Lawan (n 120) 312-13; RO Olaniyi, 'Hisbah and Sharia Law Enforcement in Metropolitan Kano' (2011) 57 Africa Today 70.

125 VO Nmehielle, 'Sharia Law in the Northern States of Nigeria: To Implement or Not to Implement, the Constitutionality is the Question' (2004) 26 Human Rights Quarterly 730.

126 Ibid; Lawan (n 120); Suberu (n 112); Bolaji (n 111).

127 Nmehielle (n 125) 310.

128 R Loimeier, 'Boko Haram: The Development of a Militant Religious Movement in Nigeria' (2012) 47 Africa Spectrum 137.

129 Suberu (n 112) 553.

${ }^{130}$ D Plang, 'Sharia Penal Laws in Northern Nigeria: A Review' in EEO Alemika (ed), Human Rights and Shariah Penal Code in Northern Nigeria (Human Rights Monitor, Kaduna, 2005) 69136; M Laden, 'Legal Pluralism and the Development of the Rule of Law in Nigeria: Issues and Challenges in the Development and Application of the Sharia' in J Ibrahim (ed), Sharia Penal and 
nineteen Northern states, twelve chose to take Sharia reforms. The Sharia implementing states have adopted one of three approaches. ${ }^{131}$ The first is the Zamfara model, which is followed by the majority of states: reintroducing Sharia and its court system by abolishing Area Courts. The second is the Kaduna/Gombe model, which establishes Sharia and customary courts by abolishing Area Courts for Muslims and non-Muslims respectively. ${ }^{132}$ The third is the Niger/Kebbi model, which maintains Area Courts; these have jurisdiction over persons who profess Islamic religion or consenting nonMuslims. ${ }^{133}$ Thus Shariacracy has been implemented fully with the federal structure.

Equally with its advancement, Shariacracy has been practised within the institutional frameworks of the federation. In addition to the federal character principle, which permeates the legislative and executive composition of the states, including the political party system, the federal allocation of resources for the implementation of Shariacracy is further evidence that it has been implemented within the constitutional framework. The Shariaimplementing states rely on the Nigeria Police Force, the single police force of the federation, for the implementation of their Sharia criminal justice systems. Further, the Sharia-implementing states submit their legislative undertakings and judicial practices to higher courts of the federation. Although the position of the federal government on the constitutionality of Shariacracy is not consistent, ${ }^{134}$ sometimes saying that it is constitutional and at other times that it is unconstitutional, it has neither asked the Nigerian Supreme Court about the constitutionality of such measures, nor will it do so in the foreseeable future. ${ }^{135}$ In light of these circumstances, the practice of Shariacracy is presumed to be consistent with the constitutional system of Nigeria. On normative grounds, however, the practice of Shariacracy is not consistent with the constitutional rights enshrined under the Nigerian Constitution. ${ }^{136}$ A series of Sharia cases affirm that Shariacracy cannot exist without violating human rights. ${ }^{137}$ For instance, Buba Jangebei suffered amputation for stealing a cow in 2000 in Zamfara state, and Amina Lawal was sentenced to death by stoning for adultery in Katsina state in

Family Laws in Nigeria and in the Muslim World: Rights Based Approach (Global Rights, Abuja, 2004) 57-113.

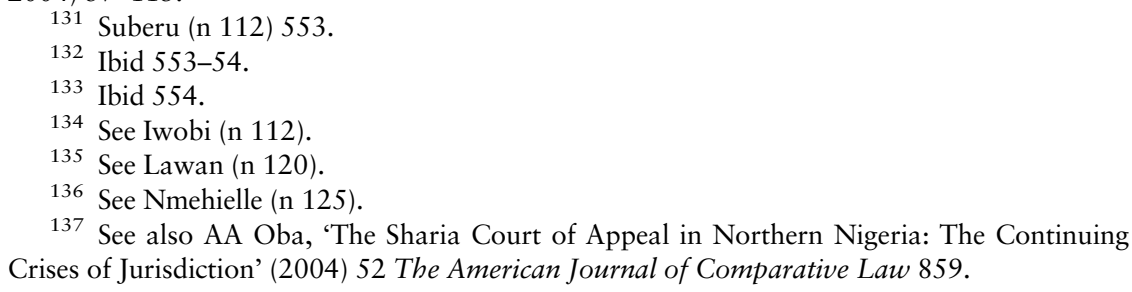

137 See also AA Oba, 'The Sharia Court of Appeal in Northern Nigeria: The Continuing Crises of Jurisdiction' (2004) 52 The American Journal of Comparative Law 859. 
2002 according to Sharia law (although the decision was reversed on procedural grounds). ${ }^{138}$

Thus, the existence of Shariacracy with constitutional democracy in a single constitutional order and the former's advancement through the latter is possible through the practice, if not the design, of constitutional jurisgenesis. The paideic communities that follow Shariacracy and the state, which implants a constitutional order and adheres to jurisgenerative narratives, make their coexistence and operation within a single constitutional universe possible. Unlike the case of women's rights, federalism has played an important role in the development and institutionalization of Shariacracy. However, it is the practice of jurisgenerative constitutionalism, not jurispathic constitutionalism, that makes this possible. Consider, for instance, the jurispathic constitutional alternative; the federal government or the Supreme Court rejects Shariacracy as unconstitutional. Such declaration of unconstitutionality will probably either bring prolonged conflict and chaos, which would make the practice of constitutional theocracy (Shariacracy) and constitutional democracy difficult, or the disintegration of Nigeria, which would make the rise of a pure constitutional theocracy in the North possible and weaken the socio-economic and political conditions of both the North and the South. In such circumstances, jurisgenerative constitutionalism provides the procedural and normative frameworks to solve some existential and system-threatening constitutional problems.

\section{Conclusion}

Global constitutionalism in Africa refers not only to the processes of constitutionalization of the international legal regime or the emergence of global constitutional law, but also to the constitution of a state of affairs that makes the experiment of constitutionalism in its many variants possible. This is because global constitutionalism 1.0 and global constitutionalism 2.0 have contributed significantly to the creation of geographical and theoretical conditions for constitutionalism in Africa. As such, for better or worse, global constitutionalism is one of the constitutive elements of constitutionalism in Africa. However, global constitutionalism's constitutive role in Africa was not imposed onto a tabula rasa; rather, it was configured in a biosphere of cultural diversity.

With regard to claims of overcoming the inherent contradictions of being born from a colony, on the one hand, and the quest for reimagining

138 JI Elaigwu and H Galadima, 'The Shadow of Sharia over Nigerian Federalism' (2003) 33 Publius: The Journal of Federalism 123, 123; Iwobi (n 112) 143. 
independence and self-determination on their own terms on the other, postcolonial African states have made global constitutionalism 2.0 a subject of continuous negation and affirmation. From the continuous negation and affirmation of global constitutionalism 2.0, two developments emerge in the practice of constitutionalism in Africa. The first (at least in principle) is a normative commitment to and an unequivocal acceptance of democracy, human rights and the rule of law for Africa's constitutional government. The second development is the simultaneous demands for the recognition of cultural diversity in the normative and institutional frameworks of both constitutions and constitutionalism.

The dual commitment to global constitutionalism 2.0 and cultural diversity has led to the emergence of jurisgenerative constitutionalism. The singularity of the constitutional order lies not in having a singular conception of justice, rights and values, but in its ability to provide a framework within which various pluralities exist and operate within the polity. As such, the constitutional order is procedurally and normatively open to accommodate seemingly competing pluralisms. Accordingly, what is constitutionally permissible and what is not cannot simply be determined by an attachment to either global constitutionalism or cultural diversity. It is the interaction of these systems in time and place that dictates what the constitutional practice or outcome should look like.

The women's rights jurisprudence and the phenomenon of Shariacracy in Nigeria are good examples of jurisgenerative constitutionalism. On the one hand, the constitutional jurisgenesis with regard to women's rights under customary laws leads to the transformation of the normative universe of the customary towards gender equality and justice. Accordingly, such constitutional jurisgenesis played a redemptive role in transforming the world of women as justice-seeking actors within their own customary systems and the broader constitutional order. On the other hand, the constitutional jurisgenesis related to women's rights under Islamic law and the phenomenon of Shariacracy has opened possibilities for the existence and operation of multiple nomos and narratives within the constitutional order. Consequently, it secures the insular autonomy or self-government of the Muslim community to live under the dictates of Sharia within and in light of the broader constitutional universe. Such jurisgenerative constitutionalism has helped Nigeria to both maintain and build its constitutional order.

The African experience sheds some light on the emerging field of global constitutionalism 2.0 in several ways. First, the dual commitment to global constitutionalism 2.0 and cultural diversity should not be considered as a resistance to or a negation of the values of human rights, democracy and the rule of law. Second, the theoretical and practical reach of global constitutionalism 2.0, if it wants to be truly global, should not be limited to the 
jurispathic constitutionalism that crowns liberal values over other cultural systems. Third, global constitutionalism 2.0 can register jurisgenerative constitutionalism as one of its experiments or manifestations. ${ }^{139}$

\section{Acknowledgements}

I am very grateful to Ran Hirschl for his invaluable support, guidance, and mentorship, from which this article and I have benefited immensely. I wish to express my profound gratitude to the editorial team of Global Constitutionalism and PluriCourts for organizing the 'Scholars Workshop: New Thinking in Global Constitutionalism' in Berlin in July 2019 and to the participants for their constructive comments and feedback, especially to Jonathan Havercroft and Geir Ulfstein. I would like to thank the organizers and participants of the Joint Work-in-Progress Seminar of the Department of Ethics, Law, and Politics and the Max Planck Fellow Group in Comparative Constitutionalism at the Max Planck Institute for the Study of Religious and Ethnic Diversity, especially Ayelet Shachar, Mariana Velasco Rivera, Lisa Harms, Alexander Hudson, and Martijn van den Brink for their insightful comments and suggestions. I am also indebted to the Melbourne Institute of Comparative Constitutional Law for organizing the 'Young Scholars Forum' in Melbourne in December 2019 and to the participants for their helpful feedback, especially to Adrienne Stone and Patrick Emerton. Finally, I am thankful to the anonymous reviewers for their very constructive comments and helpful suggestions. But, any errors or shortcomings in this article are solely mine.

139 See also M Tushnet, 'The Globalisation of Constitutional Law as a Weakly Neo-Liberal Project' (2019) 8 Global Constitutionalism 29, 39 (recommending for a plural account of global constitutionalism). 